\section{Item Response Theory-based validation of a short form of the Disordered Eating Attitude Scale (DEAS-s) to a Brazilian sample}

\author{
Validação de uma versão breve da Disordered \\ Eating Attitude Scale (DEAS-s) em uma amostra \\ brasileira com base na Teoria da Resposta \\ ao Item
}

\section{Validación de una versión breve de la Disordered Eating Attitude Scale (DEAS-s) en una muestra brasileña basada en la Teoría de la Respuesta al Ítem}

Marle dos Santos Alvarenga 1 Thanise Sabrina Souza Santos 1 Dalton Andrade 2

doi: 10.1590/0102-311X00169919

\begin{abstract}
This study aimed to validate a short version of the Disordered Eating Attitude Scale (DEAS-s). To this end, 2,902 adult individuals answered the original DEAS and informed age, weight, and height. Data were analyzed using the full-information factor analysis and Item Response Theory (IRT) analysis. Exclusion criteria retained items with adequate values of commonality and factor loadings. Estimation of IRT parameters, the Item Characteristic Curve (ICC), and test information guided the selection of the best quality items. The final model adjustment was evaluated using Root Mean Square Error of Approximation (RMSEA), Standardized Root Mean Square Residual (SRMSR), Comparative Fit Index (CFI), and Tucker-Lewis Index (TLI). The eating attitudes on each level of DEAS-s were described. The analyses were performed on $R$ software and Microsoft Excel version 2013. As results, six items were excluded because of the low communalities and factor loadings, and one more was excluded because of an overlapping on the ICC. The remaining 17 items explained 0.53 of the total variance and had an adequate goodness-of-fit (RMSEA $=0.05 ;$ SRMSR $=0.05 ; C F I=0.98 ; T L I=0.98)$. The information test is more accurate between the scores 0 and +3 . Scores higher or equal to 1.5 identified individuals with disordered eating attitudes. Women, older individuals, and those with a higher body mass index presented more disordered eating; thus, the one-dimensional and short version of DEAS showed a suitable adjustment and may contribute to properly evaluate disordered eating in diverse populations.
\end{abstract}

Psychometrics; Multivariate Analysis; Eating Disorders; Questionnaires; Reliability and Validity

\author{
Correspondence \\ M. S. Alvarenga \\ Rua Cotoxó 303, sala 127, São Paulo, SP 05021-000, Brasil. \\ marlealvarenga@gmail.com \\ 1 Universidade de São Paulo, Sâo Paulo, Brasil. \\ 2 Universidade de Santa Catarina, Florianópolis, Brasil.
}




\section{Introduction}

Disordered eating could be defined as all spectrum of problems related to food, from simple diet to clinical eating disorders 1,2 ; hence, some publications use the term to refer to patients with eating disorders or diagnostic, others to refer to dysfunctional eating behaviors (such as purgative practices, binge eating and restriction) to lose or control weight, which occur less frequently or in a less severe way than eating disorders diagnostic criteria 3,4,5,6

Disordered eating behaviors are observed mostly in the young female people and described as "epidemic" in teenagers and college students 7,8,9,10 - and are related to debilitating and costly health conditions. Disordered eating has been associated to the development of classical eating disorders 11 , with obesity 12,13 and perpetuation of overweight progress 14,15. Disordered eating also leads to diverse psychological and behavioral consequences, e.g. severe stress, low self-esteem, mood disorders, personality problems, and alcohol and drug abuse 11,16,17,18,19.

Disordered eating is evaluated using multiple instruments and terms (e.g. risk for eating disorders, abnormal eating attitudes) in the literature. Among validated questionnaires worldwide 7,19,20, Eating Attitude Test (EAT) and Bulimic Investigatory Test of Edinburgh 7,19,20 had their psychometric properties evaluated for adolescents in Brazilian context 21,22. All of them were developed in the context of clinical eating disorders screening, and EAT, specifically, has many limitations 23 .

The Disordered Eating Attitude Scale (DEAS) was developed aiming to approach specifically disordered attitudes (not eating disorders symptoms), including dysfunctional beliefs, thoughts, feelings, and relationship with food 24. It was developed and validated in Brazil with female college students and has an English 25, Spanish 26, and Japanese 27 adapted versions for young female population. DEAS psychometric properties were also evaluated when it was answered by men 28 and adolescents 29 .

DEAS psychometric properties were previously studied using the classical test theory (e.g. exploratory factor analysis with estimation by principal components using varimax rotation). However, the classical approach has some limitations, such as the focus on the test overall. On the other hand, the Item Response Theory (IRT) analysis concerns the quality and requirement of each item on the test. Likewise, the items characteristics remain constant while the test is applied in other samples. IRT analysis also enables the selection of more accurate items set improving the development of short versions of the test. Furthermore, when using the IRT analysis, the scores are calculated based on a probabilistic model and not on the sum of the correct answers 30,31,32.

Therefore, this study aimed to determine the feasibility of a unidimensional short version of DEAS (DEAS-s) using an item response theory-based methodology. This is reasonable because DEAS is almost ten years old now, the disordered eating research has increased in this period, and short (and high quality) scales are declared as ideal. Even with possibility of reduced variance (and impact on reliability and validity), short versions can improve assessment saving time and effort and increasing response rate 33 ; in addition to be included together with other measures on eating in broader studies.

\section{Material and methods}

This psychometric study included 2,490 Brazilian college students from the five different regions of the country 34, 228 male college students from the study of validation for this population 28,147 female patients with eating disorders ( 42 with anorexia nervosa, 52 bulimia nervosa, 53 binge eating disorder), and 37 obese female women without eating disorder symptoms 35 in treatment in the Clinics Hospital of Medical School at University of São Paulo (USP), Brazil. All of them answered the original DEAS 2 in paper and pencil in their universities or in the hospital area.

All individuals reported age, weight and height (self-informed in the case of students and measured in the case of patients). Body mass index (BMI; kg/m²) was calculated as weight (in kilograms) divided by the square of height (in meters). The values of BMI were classified in thinness $\left(<18.5 \mathrm{~kg} / \mathrm{m}^{2}\right)$, normal weight $\left(\geq 18.5 \mathrm{~kg} / \mathrm{m}^{2}\right.$ and $\left.\leq 24.99 \mathrm{~kg} / \mathrm{m}^{2}\right)$, and overweight $\left(\geq 25 \mathrm{~kg} / \mathrm{m}^{2}\right) 36$. 


\section{The DEAS scale}

The original DEAS had 25 items divided into 5 factors, which explained $54.3 \%$ of the total variance, and had Cronbach's alpha equal to $0.88,0.72,0.65,0.43,0.51$, respectively 24 .

Before starting IRT analysis, we decided to exclude item 1, which stated "mark how healthy and necessary you consider consumption of each kind of food", and a list of 12 food items divided in part a, b, and c. These food items were previously analyzed as different items in the factor analysis 24 . This exclusion was decided for conceptual reasons. Food classification was based on data from patients with eating disorder, following no scientific or theoretical rule or guideline. Hence, we considered it lacks epistemological basis to define the answers for this question as disordered or healthy regardless of the context and other variables. Consequently, IRT analysis started with the remained 24 DEAS items.

\section{Data analysis}

To develop a unidimensional short version of DEAS, a full-information factor analysis was performed using the package mirt on R software (http://www.r-project.org). Unidimensionality is endorsed by an explained variance of the first factor higher than $20 \%$ of the total variance 37 . Alvarenga et al. 24 had identified that the first factor explains approximately $28 \%$ of the total variance. While performing the full-information factor analysis, items with commonality lower than 0.4 and factor loadings lower than 0.3 were excluded from further analyses 38,39 .

The graded response model was used to calculate the probability of a person to choose the category $\mathrm{k}$ from each item, with a given level of the latent trait (disordered attitudes). Equation 1 represents this model 40 :

$$
P_{i, k}\left(\theta_{j}\right)=\frac{1}{1+\exp ^{-a_{i}\left(\theta_{j}-b_{i, k}\right)}}-\frac{1}{1+\exp ^{-a_{i}\left(\theta_{j}-b_{i, k+1}\right)}}
$$

where: $\theta_{j}$ is the IRT score of a person $j ; P_{i, k}\left(\theta_{j}\right)$ is the probability of a person $j$, when answering the item $i$, choosing the category $k ; a_{i}$ is the discrimination parameter of item $i$; $b_{i, k}$ is the location parameter of the category $k$ of the item $i$, with $\mathrm{b}_{\mathrm{i}, 2} \leq \mathrm{b}_{\mathrm{i}, 3} \leq \mathrm{b}_{\mathrm{i}, 4} \leq \ldots$

The discrimination parameter $\left(a_{i}\right)$ indicates the quality of the item to discriminate people with different level of disordered attitudes. Items had adequate discrimination of the latent trait when parameter ai was higher than or equal to 0.741 . Parameter $b_{i}$ should range mostly from -3 to +342 .

Both parameters $\left(a_{i}\right.$ and $\left.b_{i}\right)$ were estimated by the marginal maximum likelihood method considering a convergence criterion equal to 0.001 . Parameter $b_{i}$ and IRT scores were estimated in a scale with mean equal to 0 and standard deviation equal to 142 . These estimates may be also analyzed in the Item Characteristic Curve (ICC). Figure 1 shows an example of ICC for the item "I feel guilty when I eat something that I thought I should not eat for some reason". This item has the discrimination parameter equal to 2.24 and location parameters equal $-0.49 ; 0.70$; and 1.45 , respectively for categories 2,3 , and 4 .

The estimates were analyzed with the corresponding standard error. The items that did not adhere to the acceptable requirements were excluded from further analysis. The response categories of items with overlapping on the ICC were reorganized considering the conceptual reasons. The final model considered only those items with adequate values of parameters ai and bi and their standard errors.

The internal consistency of the items in the final model was evaluated using the Cronbach's alpha in the package psych on R software. The questionnaire is internally consistent when alpha is higher than 0.738 . The effect of the exclusion of each item on the alpha value was also evaluated.

The adjustment of the final model was evaluated underlying the Root Mean Square Error of Approximation (RMSEA), the Standardized Root Mean Square Residual (SRMSR), the Comparative Fit Index (CFI), and the Tucker-Lewis Index (TLI) 43,44. The goodness-of-fit was confirmed when the RMSEA and SRMSR were less or equal to 0.05 and the CIF and TLI were higher than 0.9045 . Accuracy was also analyzed by the Test Information Curve. IRT and adjustment analyses were performed using the package mirt on R software.

The probability to choose the category $\mathrm{k}$ was calculated across the scores, considering the location parameters for each item. To describe the eating attitudes of each level of DEAS-s, each item was located at the level in which the probability was higher or equal to 0.5. Two nutritionists (M.S.A. and 


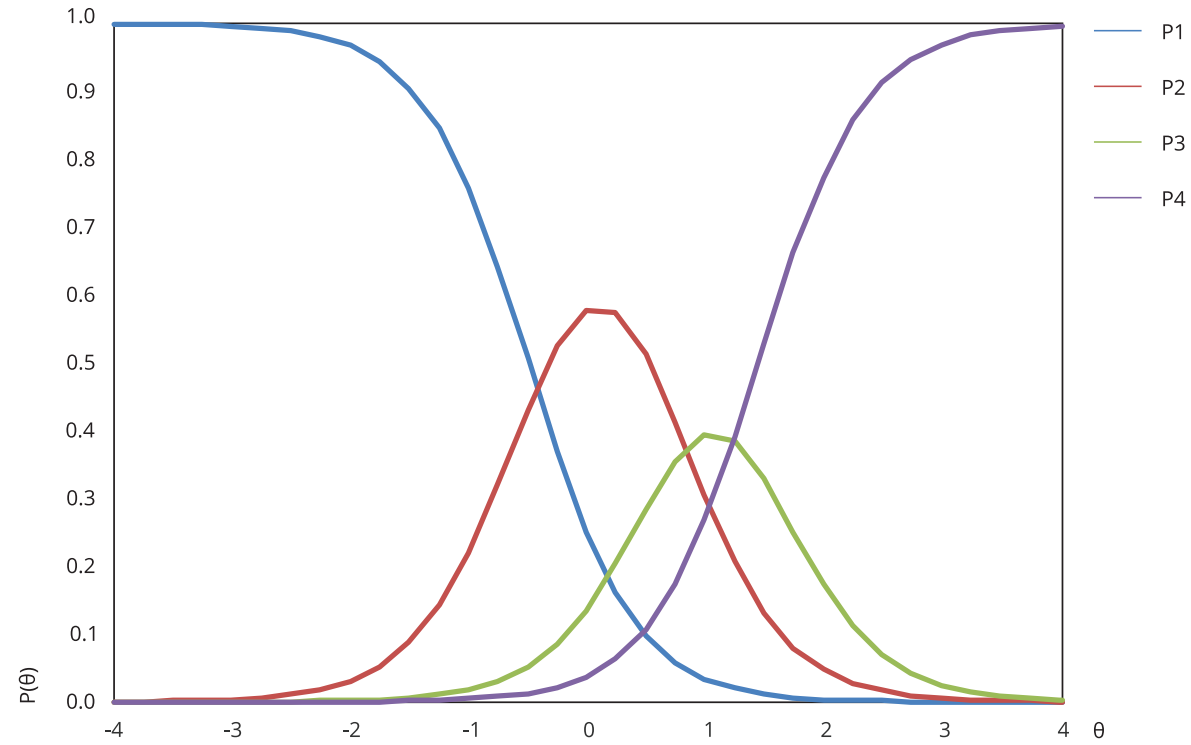

$\theta$ : Item Response Theory (IRT) score; P( $(\theta)$ : probability of a person to choose the category; P1: characteristic curve of the category 1 (never); P2: characteristic curve of the category 2 (sometimes); P3: characteristic curve of the category 3 (frequently); P4: characteristic curve of the category 4 (always).

T.S.S.S.) analyzed this description and identified the score from which the individuals have disordered eating attitudes using Microsoft Excel version 2013 (https://products.office.com/). Moreover, to improve the interpretability of the DEAS evaluated by IRT 46, the scores estimated in a scale with mean equal to 0 and standard deviation equal to 1 were transformed to a scale with mean equal to 50 and standard deviation equal to 10 .

Chi-square test was performed to evaluate differences in the sample characteristics regarding sex, age (less than or equal to 19 - since the World Health Organization defines adolescence from 10 to 19 years of age 47 -, 20 to 30 years old; and $\geq 31$ years old), and BMI by disordered eating attitudes.

All the original studies using DEAS were approved by the Research Ethics Committee of the School of Public Health, USP 28,34,35.

\section{Results}

Most participants included in the current analyses were women (92.1\%), younger than 30 (85.8\%) and had a BMI lower than $24.99 \mathrm{~kg} / \mathrm{m}^{2}(79.9 \%)$.

Six items were excluded in the full-information factor analysis because of the low values for communalities and factor loadings.

Namely, these are the items excluded before performing the IRT analysis: "Do you feel pleasure when you eat?"; "Do you enjoy the feeling of an empty stomach?"; "Do you have good memories related to food?"; "Do you believe that it is normal to eat sometimes just because you are sad, upset or bored?"; "I worry all the time about what I am going to eat, how much to eat, how to prepare food and whether I should eat or not"; and "When I desire a specific kind of food, I know I will not stop eating until I have finished with it".

IRT analysis was performed in the remaining 18 items. All items presented adequate discrimination parameter. Nevertheless, the item "I would like to have my appetite and eating behavior under total 
control" presented an overlapping on the ICC after various attempts of re-categorization and was excluded. Finally, IRT analysis was also performed considering only the 17 items (for full description and codification system see Supplementary Material 1: http://cadernos.ensp.fiocruz.br/site/ public_site/arquivo/suppl-1-e00169919_3298.pdf). These items explained 0.53 of the total variance in full-information factor analysis; the estimation of the IRT parameters was completed with 20 EM cycles. Table 1 shows the factor loadings, communalities and IRT parameters $\left(a_{i}, b_{i}\right.$, and their standard errors) of the 17 remained items and Supplementary Material 2 (http://cadernos.ensp.fiocruz.br/site/ public_site/arquivo/suppl-2-e00169919_8064.pdf) presents their item characteristic curves.

The items on the exclusion of some foods (items 4 and 14) have the lowest discrimination parameter $\left(a_{4}=1.47\right.$ and $\left.a_{14}=1.48\right)$. The best discrimination parameter is found for the item on the effect of the relationship with food in life as a whole $\left(\mathrm{a}_{25}=2.65\right)$.

Guilt after eating was observed at the lowest levels of DEAS-s $\left(b_{13,2}=-0.49\right)$, suggesting thoughts regarding some foods that should be not eaten are sometimes presented by individuals with the lowest scores of DEAS-s. Besides the lowest discrimination $\left(\mathrm{a}_{14}=1.48\right)$, item 14 also had the highest value for the location parameter $\left(b_{14,4}=2.63\right)$, suggesting the exclusion of some food because of the calories is more frequent at the highest levels of disordered eating.

The final model presented an adequate internal consistency (Cronbach's alpha equal to 0.88 ) and goodness-of-fit $(\mathrm{RMSEA}=0.05$; SRMSR $=0.05 ; \mathrm{CIF}=0.98$; and $\mathrm{TLI}=0.98)$. The information test suggested a better accuracy between the scores 0 and +3 (Figure 2).

\section{Table 1}

Factor loadings, communalities, and discrimination and location parameters (and respective standard errors) of 17 items from the short version of the Disordered Eating Attitude Scale (DEAS-s) evaluated by Item Response Theory.

\begin{tabular}{|c|c|c|c|c|c|c|c|c|c|c|}
\hline Item & Factor loading & $h^{2}$ & a & $\mathrm{SE}_{\mathrm{a}}$ & $b_{2}$ & $\mathrm{SE}_{\mathrm{b} 2}$ & $b_{3}$ & $\mathrm{SE}_{\mathrm{b3}}$ & $\mathbf{b}_{4}$ & $\mathrm{SE}_{\mathrm{b} 4}$ \\
\hline 3 Does eating ever feel unnatural to you? & 0.76 & 0.58 & 2.01 & 0.16 & 2.43 & 0.11 & & & & \\
\hline $\begin{array}{l}4 \text { Have you ever spent one or more days without eating or having } \\
\text { only liquids because you believed you could lose weight? }\end{array}$ & 0.65 & 0.43 & 1.47 & 0.08 & 1.71 & 0.07 & & & & \\
\hline 5 Do you count the calories of everything you eat? & 0.66 & 0.44 & 1.51 & 0.09 & 1.94 & 0.08 & & & & \\
\hline 7 Do you "skip" meals to avoid putting on weight? & 0.71 & 0.50 & 1.71 & 0.08 & 0.99 & 0.04 & & & & \\
\hline 8 Does eating make you feel "dirty"? & 0.83 & 0.69 & 2.52 & 0.17 & 1.92 & 0.06 & & & & \\
\hline 10 Do you wish you did not need to eat? & 0.67 & 0.45 & 1.54 & 0.08 & 1.25 & 0.05 & & & & \\
\hline $\begin{array}{l}12 \text { When you eat more than usual, what is your behavior } \\
\text { afterwards? }\end{array}$ & 0.70 & 0.50 & 1.69 & 0.07 & 0.50 & 0.03 & 1.81 & 0.06 & & \\
\hline $\begin{array}{l}13 \text { I feel guilty when I eat something that I thought I should not eat } \\
\text { for some reason. }\end{array}$ & 0.80 & 0.63 & 2.24 & 0.08 & -0.49 & 0.03 & 0.70 & 0.03 & 1.45 & 0.04 \\
\hline $\begin{array}{l}14 \text { I quit eating a kind of food if I find out it has more calories than } \\
\text { I thought. }\end{array}$ & 0.66 & 0.43 & 1.48 & 0.06 & 0.32 & 0.04 & 1.642 & 0.06 & 2.63 & 0.10 \\
\hline $\begin{array}{l}16 \text { I worry about how much a certain kind of food or meal will } \\
\text { make me gain weight. }\end{array}$ & 0.76 & 0.58 & 1.99 & 0.07 & -0.47 & 0.03 & 0.56 & 0.03 & 1.49 & 0.05 \\
\hline 17 I am angry when I feel hungry. & 0.69 & 0.47 & 1.62 & 0.08 & & & 1.28 & 0.05 & & \\
\hline $\begin{array}{l}18 \text { It is hard to choose what to eat, because I always think I should } \\
\text { eat less or choose the option with fewer calories. }\end{array}$ & 0.81 & 0.66 & 2.39 & 0.09 & 0.08 & 0.03 & 0.91 & 0.03 & 1.66 & 0.05 \\
\hline $\begin{array}{l}\mathbf{2 1} \text { I try to eat less in front of others in order to overeat when I am } \\
\text { alone. }\end{array}$ & 0.68 & 0.47 & 1.59 & 0.11 & & & 2.20 & 0.10 & & \\
\hline 22 I am afraid of starting to eat and not being able to stop. & 0.75 & 0.56 & 1.94 & 0.08 & 0.67 & 0.03 & 1.39 & 0.05 & 2.06 & 0.07 \\
\hline 23 I dream of a pill that would replace food. & 0.79 & 0.62 & 2.19 & 0.12 & & & 1.35 & 0.05 & & \\
\hline $\begin{array}{l}24 \text { I get nervous and/or lose my self-control at parties and buffets, } \\
\text { due to a great amount of foods available. }\end{array}$ & 0.73 & 0.53 & 1.82 & 0.11 & & & 1.90 & 0.07 & & \\
\hline 25 My relationship with food messes up my life as a whole. & 0.84 & 0.71 & 2.65 & 0.16 & & & 1.52 & 0.05 & & \\
\hline
\end{tabular}

a: discrimination parameter; $b_{2}$ : location parameter of category $2 ; b_{3}$ : location parameter of category 3 ; $b_{4}$ : location parameter of category 4 ;

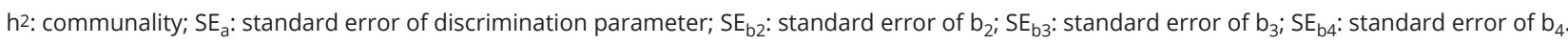


Figure 2

Test Information Curve of the short version of Disordered Eating Attitude Scale (DEAS-s) evaluated by Item Response Theory.

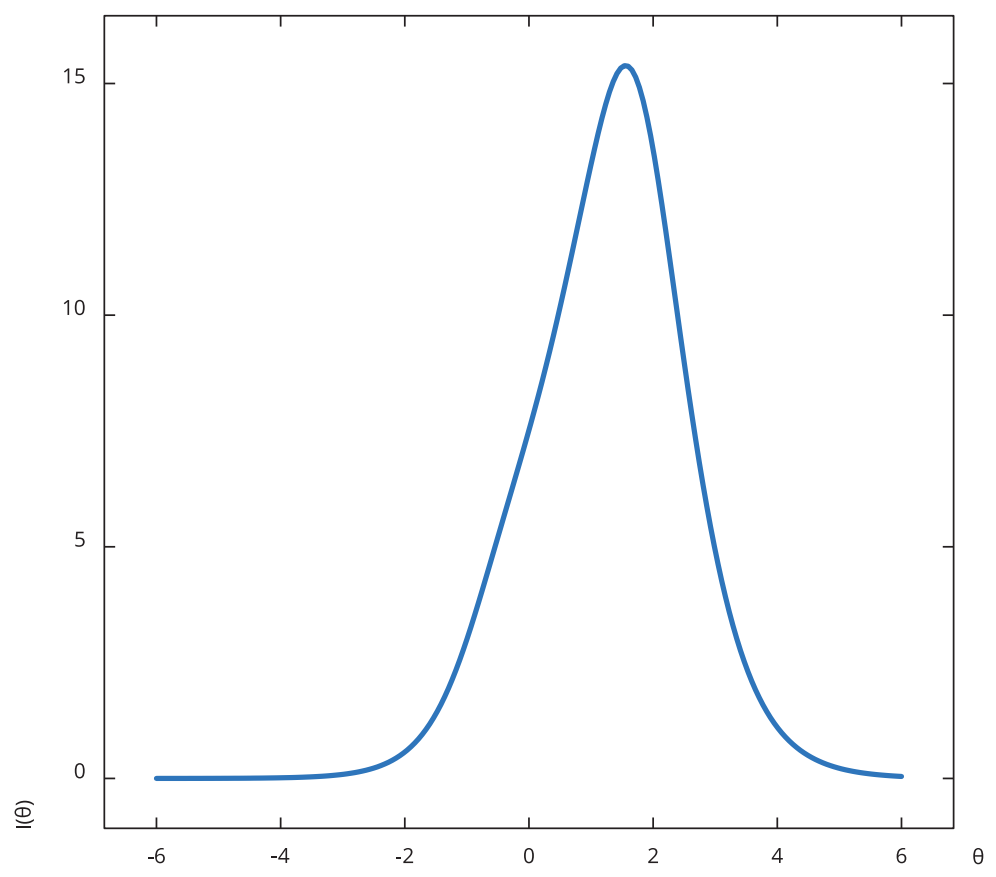

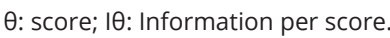

Box 1 shows a description of the eating attitudes characteristics of each level of DEAS-s. We conceptually defined that the score higher or equal to 1.5 identifies the individuals with important eating disordered attitudes. That is, from the score 1.5, individuals wish they did not need to eat and always worry about their diet and weight. Women, older individuals, and those with a higher BMI presented more disordered eating according to this defined score (Table 2).

\section{Discussion}

To develop a unidimensional short version of DEAS, this study analyzed the answers to the original questionnaire considering IRT in addition to the factor analysis. The current analysis suggested some items from the original DEAS are unable to evaluate disordered eating. Besides decreasing the number of items, the short version provides a more accurate measure and adds the description of the eating disordered attitudes across each level of the continuum.

As recommended, the sample included individuals with heterogeneous eating attitudes 30 . This was important to adequately estimate the discrimination and location parameters 30 . The individuals included in the current analyses have shown a broad range of scores in the original DEAS in previous studies 27,28,35, so mixed levels for disordered eating were expected.

The original DEAS has five factors derived from a classical analysis and conceptual reasons 22 . The first factor explained more than $20 \%$ of the total variance 24 , endorsing a unidimensional measure of disordered eating ${ }^{36}$. Moreover, it is important to consider that disordered eating is not necessarily a construct with dimensions. It has a range of characteristics, but could be unidimensional defined as disordered feelings, thoughts, behaviors and relationship with food. 
Box 1

Description of eating attitudes from each level of the short version of Disordered Eating Attitude Scale (DEAS-s) evaluated by Item Response Theory.

\begin{tabular}{|c|c|c|}
\hline Level $(0,1)$ & Level $(50,10)$ & In this level... \\
\hline-0.5 & 44.6 & $\begin{array}{l}\text { Sometimes feel guilty when eat something that thought should not eat for some reason. Sometimes worry } \\
\text { about how much a certain kind of food or meal will make gain weight. }\end{array}$ \\
\hline 0.0 & 49.9 & $\begin{array}{l}\text { Sometimes feel hard to choose what to eat, because always think should eat less or choose the option with } \\
\text { fewer calories. }\end{array}$ \\
\hline 0.5 & 55.3 & $\begin{array}{l}\text { Assume you have lost control and keep eating even more or decide to go on a diet to compensate if } \\
\text { eat more than usual. Sometimes quit eating a kind of food if find out it has more calories than thought. } \\
\text { Frequently worry about how much a certain kind of food or meal will make gain weight. }\end{array}$ \\
\hline 1.0 & 60.7 & $\begin{array}{l}\text { Skip meals to avoid putting on weight. Frequently feel guilty when eat something that thought should not } \\
\text { eat for some reason. Frequently fells hard to choose what to eat, because always think should eat less or } \\
\text { choose the option with fewer calories. Sometimes is afraid to start eating and not be able to stop. }\end{array}$ \\
\hline 1.5 & 66.1 & $\begin{array}{l}\text { Would like to not need to eat. Always feel guilty when eat something that thought should not eat for some } \\
\text { reason. Always worry about how much a certain kind of food or meal will make gain weight. Frequently fells } \\
\text { angry when feels hungry. Frequently is afraid to start eating and not be able to stop. Frequently dreams of } \\
\text { a pill that would replace food. Frequently think that relationship with food messes up life as a whole. }\end{array}$ \\
\hline 2.0 & 71.4 & $\begin{array}{l}\text { Spent one or more days without eating or having only liquids because you believe could lose weight. Count } \\
\text { the calories of everything it eats. Feels "dirty" when eating. Use some kind of compensation (e.g. physical } \\
\text { activity, vomiting, laxatives and diuretics) if eat more than usual. Frequently quit eating a kind of food if find } \\
\text { out it has more calories than thought. Always fells hard to choose what to eat, because always think should } \\
\text { eat less or choose the option with fewer calories. Frequently get nervous and/or lose self-control at parties } \\
\text { and buffets, due to a great amount of foods available. }\end{array}$ \\
\hline 2.5 & 76.8 & $\begin{array}{l}\text { Think eating feels unnatural. Frequently try eating less in front of others in order to overeat when alone. } \\
\text { Always is afraid to start eating and not be able to stop. Always quit eating a kind of food if find out it has } \\
\text { more calories than thought. }\end{array}$ \\
\hline
\end{tabular}

Table 2

Disordered eating according to the shorter version of the Disordered Eating Attitude Scale (DEAS-s) by sex, age and body mass index (BMI).

\begin{tabular}{|c|c|c|c|c|c|c|c|}
\hline & \multirow[t]{2}{*}{$\mathbf{N}$} & \multirow[t]{2}{*}{$\%$} & \multicolumn{4}{|c|}{ Disordered eating } & \multirow[t]{2}{*}{ p-value * } \\
\hline & & & No $(n=2,712)$ & $\%(93.5)$ & Yes $(n=189)$ & $\%(6.5)$ & \\
\hline $\operatorname{Sex}(n=2,901)$ & & & & & & & $<0.001$ \\
\hline Male & 228 & 7.9 & 225 & 8.3 & 3 & 1.6 & \\
\hline Female & 2,673 & 92.1 & 2,487 & 91.7 & 186 & 98.4 & \\
\hline Age (years) $(n=2,835)$ & & & & & & & 0.007 \\
\hline$\leq 19$ & 745 & 26.3 & 709 & 26.8 & 36 & 19.2 & \\
\hline$\geq 20$ and $\leq 30$ & 1,686 & 59.5 & 1,574 & 59.4 & 112 & 59.9 & \\
\hline BMI $(n=2,749)$ & & & & & & & $<0.001$ \\
\hline Thinness & 272 & 9.9 & 245 & 9.5 & 27 & 16.2 & \\
\hline Normal weight & 1,924 & 70.0 & 1,847 & 71.5 & 77 & 46.1 & \\
\hline Overweight & 553 & 20.1 & 490 & 19.0 & 63 & 37.7 & \\
\hline
\end{tabular}

* Likelihood ratio. 
A unidimensional and short version may improve the assessment of disordered eating because its use is more practical. In addition, the current analysis selected high-quality items to evaluate the construct 31 . DEAS-s has adequate goodness-of-fit and better psychometric properties than the original DEAS, which has factors with low reliabilities and few items 38 .

The disordered eating attitudes characteristics allocated at each level of the DEAS-s make sense in levels of "dysfunctionality". One must consider that it is more serious if someone wish they did not need to eat, and always or frequently feels guilty, afraid and worried (and even angry) related to eating. Nonetheless, disordered eating is not a diagnostic and has no "criteria" 1,2; so the DEAS development did not propose a cut-point for its score. Nevertheless, in some way, we could classify the disordered eating by levels, considering its interpretation, which could improve studies of groups' evaluations and associated variables. When using the DEAS-s, we suggest the score 1.5 as the point from which the individuals have important disordering.

In this sense, women, older individuals (20-years-old up to 30-year-old), and those with a higher BMI presented very dysfunctional attitudes, as the classical profile of eating disorder patients 2 . Other studies focusing on disordered eating (even using other instruments) also found that female sex 7,12,48 and overweight and obesity 7,12 were linked to the disordered pattern. Women are usually more concerned with eating and weight, so disordered eating behaviors should address mostly female people. When using specific questions from the original DEAS and some from EAT, Alvarenga et al. 3 found that, among Brazilian female college students, disordered eating was 50\% more prevalent in those who were overweight or obese.

The evaluation of Brazilian college students using the original DEAS had previously found higher scores for those with overweight status; but unlike this study, younger people had worse eating attitude 34 . In the current analysis, although eating disorders are more prevalent in older people, it is important to emphasize that the "older" here were those over 25 (and mostly under 30). This discussion on the weight status is fundamental to demystify the idea that overweight or obese people must be more concerned or even guilt about eating and its consequences. They usually are, but they have no weight loss or even better health because of it. In line with the current analysis, dysfunctional attitudes and behaviors with food and weight tend to be more common in overweight individuals. Disordered eating and body weight excess may perpetuate each other, since their common factors are related with both - including media influence, weight stereotypes, body dissatisfaction, dieting, emotional eating, etc. ${ }^{13}$. However, we must stress that weight and height were self-reported in the samples included in this study (with the exception of patients with eating disorders, whose weight and height were measured), which could be a limitation of the study. Nevertheless, a meta-analysis 49 concluded that selfreported height and weight are good estimates of actual measures, and some studies in Brazil show high consistency between self-reported and measured data and consider self-reported data reliable when actual measures are unavailable for epidemiological studies 50,51.

In conclusion, considering that disordered eating must be widely evaluated because of its prevalence and consequences - and must not be confused with classical eating disorder symptoms -, we need a proper instrument. DEAS had shown its possibilities in previous studies 3,34,35,52,53,54,55,56,57, but DEAS-s provided by this study could amplify its use and bring more knowledge on dysfunctional feelings, thoughts, behaviors and relationship with food. 


\section{Contributors}

All authors contributed to the study conception and design. Material preparation and data collection was performed by M. S. Alvarenga, and analysis were performed by T. S. S. Santos and D. Andrade. The first draft of the manuscript was written by M. $\mathrm{S}$. Alvarenga and all authors commented on previous versions of the manuscript. All authors read and approved the final manuscript.

\section{Conflict of interest}

The authors declare no conflict of interest regarding the publication of this paper. This research did not receive any specific grant from funding agencies in the public, commercial, or not-for-profit sectors.

\section{Additional informations}

ORCID: Marle dos Santos Alvarenga (0000-00016922-2670); Thanise Sabrina Souza Santos (00000003-4087-1815); Dalton Andrade (0000-00024403-980X).

\section{References}

1. Ozier AD, Henry BW; American Dietetic Association. Position of the American Dietetic Association: nutrition intervention in the treatment of eating disorders. J Am Diet Assoc 2011; 111:1236-41.

2. American Psychiatry Association. Practice guideline for the treatment of patients with eating disorders. 3rd Ed. https://psychiatryonline.org/pb/assets/raw/sitewide/practice_ guidelines/guidelines/eatingdisorders.pdf (accessed on 03/Oct/2018).

3. Alvarenga MS, Lourenço BH, Philippi ST, Scagliusi FB. Disordered eating among Brazilian female college students. Cad Saúde Pública 2013; 29:879-88.

4. Jacobi C, Fittig E, Bryson SW, Wilfley D, Kraemer HC, Taylor CB. Who is really at risk? Identifying risk factors for subthreshold and full syndrome eating disorders in a high-risk sample. Psychol Med 2011; 41:1939-49.

5. Kelly SD, Howe CJ, Hendler JP, Lipman TH. Disordered eating behaviors in youth with type 1 diabetes. Diabetes Educ 2005; 34:57283.

6. Sischo L, Taylor J, Martin PY. Carrying the weight of self-derogation? Disordered eating practices as social deviance in young adults. Deviant Behav 2006; 27:1-30.

7. Barrack MT, West J, Christopher M, PhamVera AM. Disordered eating among a diverse sample of first-year college students. J Am Coll Nutr 2019; 38:141-8.

8. Neumark-Sztainer D, Bauer KW, Friend S, Hannan PJ, Story M, Berge JM. Family weight talk and dieting: how much do they matter for body dissatisfaction and disordered eating behaviors in adolescent girls? J Adolesc Health 2010; 47:270-6.

9. Neumark-Sztainer D, Story M, Hannan PJ, Perry CL, Irving LM. Weight-related concerns and behaviors among overweight and nonoverweight adolescents: implications for preventing weight-related disorders. Arch Pediatr Adolesc Med 2002; 156:171-8.

10. Neumark-Sztainer D, Wall MM, Haines JI, Story MT, Sherwood NE, van den Berg PA. Shared risk and protective factors for overweight and disordered eating in adolescents. Am J Prev Med 2007; 33:359-69.

11. Hautala L, Helenius H, Karukivi M, Maunula AM, Nieminen J, Aromaa M, et al. The role of gender, affectivity and parenting in the course of disordered eating: a 4-year prospective case-control study among adolescents. Int J Nurs Stud 2011; 48:959-72.

12. Nagata JM, Garber AK, Tabler JL, Murray SB, Bibbins-Domingo K. Prevalence and correlates of disordered eating behaviors among young adults with overweight or obesity. J Gen Intern Med 2018; 33:1337-43.

13. Urquhart CS, Mihalynuk TV. Disordered eating in women: implications for the obesity pandemic. Can J Diet Pract Res 2011; 72:e11525. 
14. Hayes JF, Fitzsimmons-Craft EE, Karam AM, Jakubiak J, Brown ML, Wilfley DE. Disordered eating attitudes and behaviors in youth with overweight and obesity: implications for treatment. Curr Obes Rep 2018; 7:235-46.

15. Wright A, Pritchard ME. An examination of the relation of gender, mass media influence, and loneliness to disordered eating among college students. Eat Weight Disord 2009; 14:e144-7.

16. da Luz FQ, Sainsbury A, Mannan H, Touyz S, Mitchison D, Girosi F, et al. An investigation of relationships between disordered eating behaviors, weight/shape overvaluation and mood in the general population. Appetite 2018; 129:19-24.

17. Ferrier AG, Martens MP. Perceived incompetence and disordered eating among college students. Eat Behav 2008; 9:111-9.

18. Kärkkäinen U, Mustelin L, Raevuori A, Kaprio J, Keski-Rahkonen A. Do disordered eating behaviours have long-term health-related consequences? Eur Eat Disord Rev 2018; 26:22-8.

19. Sanlier N, Navruz Varli S, Macit MS, Mortas $\mathrm{H}$, Tatar T. Evaluation of disordered eating tendencies in young adults. Eat Weight Disord 2017; 22:623-31.

20. Leal GVS, Philippi ST, Polacow VO, Cordás TA, Alvarenga MS. O que é comportamento de risco para transtornos alimentares em adolescentes? J Bras Psiquiatr 2013; 62:62-75.

21. Bighetti F, Santos CBD, Santos JED, Ribeiro RP. Tradução e validação do Eating Attitudes Test em adolescentes do sexo feminino de Ribeirão Preto, São Paulo. J Bras Psiquiatr 2004; 53:339-46.

22. Ximenes RCC, Colares V, Bertulino T, Couto GBL, Sougey EB. Versão brasileira do BITE para uso em adolescentes. Arq Bras Psicol 2011; 63:52-63.

23. Garfinkel PE, Newman A. The eating attitudes test: twenty-five years later. Eat Weight Disord 2001; 6:1-24.

24. Alvarenga MS, Scagliusi FB, Philippi ST. Development and validity of the disordered eating attitude scale (DEAS). Percept Mot Skills 2010; 110:379-95.

25. Alvarenga MS, Pereira RF, Scagliusi FB, Philippi ST, Estima CPC, Croll J. Psychometric evaluation of the Disordered Eating Attitude Scale (DEAS) - English version. Appetite 2010; 55:374-6.

26. Alvarenga MS, Francischi R, Fontes F, Scagliusi FB, Philippi ST. Adaptación y validación al español del Disordered Eating Attitude Scale (DEAS). Perspect Nutr Hum 2010; 12:11-23.

27. Chisuwa N, Shimai S, Haruki T, Alvarenga MS. Development of the Japanese version of the Disordered Eating Attitude Scale (DEAS). School Health 2013; 9:14-22.

28. Alvarenga MS, Carvalho PHB, Philippi ST, Scagliusi FB. Propriedades psicométricas da Escala de Atitudes Alimentares Transtornadas para adultos do sexo masculino. J Bras Psiquiatr 2014; 62:253-60.
29. Alvarenga MS, Koritar P, Pinzon VD, Figueiredo M, Fleitlich-Bilyk B, Philippi ST, et al. Validation of the Disordered Eating Attitude Scale for adolescents. J Bras Psiquiatr 2016; 65:3643.

30. Bortolotti SLV, Tezza R, Andrade DF, Bornia AC, Sousa Júnior AF. Relevance and advantages of using the item response theory. Qual Quant 2013; 47:2341-60.

31. Santos TSS, Julian C, Andrade DF, Villar BS, Piccinelli R, González-Gross M, et al. Measuring nutritional knowledge using Item Response Theory and its validity in European adolescents. Public Health Nutr 2018; 22:419 30.

32. Sekely A, Taylor GJ, Bagby RM. Developing a short version of the Toronto Structured Interview for Alexithymia using item response theory. Psychiatry Res 2018; 266:218-27.

33. Dodeen H, Al-Darmaki F. The application of item response theory in developing and validating a shortened version of the Emirate Marital Satisfaction Scale. Psychol Assess 2016; 28:1625-33.

34. Alvarenga MS, Scagliusi FB, Philippi ST. Comparison of eating attitudes among university students from the five Brazilian regions. Ciênc Saúde Colet 2011; 17:435-44.

35. Alvarenga MS, Koritar P, Pisciolaro F, Mancini M, Cordas TA, Scagliusi FB. Eating attitudes of anorexia nervosa, bulimia nervosa, binge eating disorder and obesity without eating disorder female patients: differences and similarities. Physiol Behav 2014; 131:99-104.

36. World Health Organization. Physical status: the use and interpretation of anthropometry. Report of a WHO Expert Committee. https:// www.who.int/childgrowth/publications/phys ical_status/en/ (accessed on 18/Aug/2018).

37. Reckase MD. Unifactor latent trait models applied to multifactor tests: results and implications. J Educ Behav Stat 1979; 4:207-30.

38. Hair JF, Black WC, Babin BJ, Anderson RE, Tatham RL. Análise multivariada de dados. Porto Alegre: Bookman; 2009.

39. Tabachnick BG, Fidell LS. Using multivariate statistics. 6th Ed. New Jersey: Prentice Hall; 2013.

40. Samejima FA. Estimation of latent ability using a response pattern of graded scores. Richmond: Psychometric Society; 1969. (Psychometric Monograph, 17)

41. Tezza R, Bornia AC, Andrade DF. Measurement web usability using item response theory: principles, features and opportunities. Interact Comput 2011; 23:167-75.

42. Chernyshenko OS, Stark S, Chan KY, Drasgow F, Williams B. Fitting item response theory models to two personality inventories: issues and insights. Multivariate Behav Res 2001; 36:523-62.

43. Browne MW, Cudeck R. Alternative ways of assessing model fit. In: Bollen K, Long J, editors. Testing structural equation models. Newbury Park: Sage; 1993. p. 136-62. 
44. Maydeu-Olivares A. Goodness-of-fit assessment of item response theory models. Measurement (Mahwah N J) 2013; 11:71-101.

45. Brown TA. Confirmatory factor analysis for applied research. New York: The Guilford Press; 2015.

46. Andrade DF, Tavares HR, Valle RC. Teoria de resposta ao item: conceitos e aplicações. São Paulo: Associação Brasileira de Estatística; 2000.

47. World Health Organization. Young people's health - a challenge for society. Report of a WHO Study Group on Young People and Health for All. Geneva: World Health Organization; 1986. (WHO Technical Report Series, 731).

48. MacNeill LP, Best LA, Davis LL. The role of personality in body image dissatisfaction and disordered eating: discrepancies between men and women. J Eat Disord 2017; 5:44.

49. Bowman R, De Lucia J. Accuracy of self-reported weight: a meta-analysis. Behav Ther 1992; 23:637-55.

50. Fonseca MJM, Faerstein E, Chor D, Lopes CS. Validade de peso e estatura informados e índice de massa corporal: Estudo Pró-Saúde. Rev Saúde Pública 2004; 38:392-8.

51. Peixoto MRG, Benicio MHD, Veiga PCB. Validade do peso e da altura auto-referidos: o estudo de Goiânia. Rev Saúde Pública 2006; 40:1065-72.
52. Alvarenga MS, Scagliusi FB, Philippi ST. Eating attitudes of female Brazilian university students with eating disorder risk behavior. Journal of Behavioral Health Social Issues 2010; 2:47-54.

53. Claumann GS, Klen JA, Dias DT, Gonzaga I, de Araújo Pinto A, Pelegrini A. Atitudes alimentares de praticantes de treinamento resistido. Revista Brasileira de Nutrição Esportiva 2017; 11:898-909.

54. Jo HB, Kim JM. The effect of personality style and emotion dysregulation on female adolescents eating attitude: a comparison between different body mass index (BMI) groups. Journal of Korean Home Management Association 2015; 33:55-70.

55. Meyer LK, Stanick CF. College students' relationship between trauma and disordered eating. J Coll Stud Psychother 2018; 32:242-50.

56. Privitera GJ, Dickinson EK. Control your cravings: self-controlled food choice varies by eating attitudes, sex, and food type among Division I collegiate athletes. Psychol Sport Exerc 2015; 19:18-22.

57. Ulian MD, Benatti FB, de Campos-Ferraz PL, Roble OJ, Unsain RF, de Morais Sato P, et al. The effects of a "health at every size ${ }^{\circledR}$ "-based approach in obese women: a pilot-trial of the "health and Wellness in Obesity" study. Front Nutr 2015; 2:34. 


\section{Resumo}

O objetivo do estudo foi validar uma versão breve da Disordered Eating Attitude Scale (DEAS-s). Um total de 2.902 adultos responderam à DEAS original e informaram a idade, peso e altura. Os dados foram analisados com a análise fatorial por informação completa e Teoria da Resposta ao Item (TRI). Os critérios de exclusão retiveram itens com valores adequados de comunalidades e cargas fatoriais. A estimação dos parâmetros TRI, a Curva Característica do Item (CCI) e teste de informação orientaram a seleção de itens com melhor qualidade. $O$ ajuste do modelo final foi avaliado com a Raiz da Média dos Quadrados dos Erros de Aproximação (RMSEA), Raiz Padronizada da Média Quadrática Residual (SRMSR), Índice de Ajuste Comparativo (CFI) e Índice de Tucker-Lewis (TLI). Foram descritas as atitudes alimentares em cada nível da DEAS-s. As análises foram realizadas no software $R$ e no Microsoft Excel, versão 2013. Nos resultados, seis itens foram excluídos devido às comunalidades e cargas fatoriais baixas, e mais um item foi excluído devido a uma sobreposição na CCI. Os 17 itens restantes explicaram 0,53 da variância total e mostraram ajuste adequado (RMSEA $=0,05 ;$ SRMSR $=0,05$; $C F I=0,98 ; T L I=0,98)$. O teste de informação é mais acurado entre os escores entre $\mathrm{O} e+3$. Valores maiores ou iguais a 1,5 identificaram os indivíduos com comer transtornado. As mulheres, os individuos mais velhos e aqueles com indice de mass a corporal mais elevado apresentaram mais comer transtornado. Portanto, a versão unidimensional e breve da DEAS mostrou ajuste adequado e pode contribuir para a avaliação correta dos transtornos alimentares em populações distintas.

Psicometria; Análise Multivariada; Transtornos da Ingestão de Alimentos; Questionários; Confiabilidade e Validade

\section{Resumen}

El objetivo del estudio fue validar una versión breve de la Disordered Eating Attitude Scale (DEAS-s). Un total de 2.902 adultos respondieron a la DEAS original e informaron la edad, peso $y$ altura. Los datos fueron analizados mediante análisis factorial por información completa y Teoría de la Respuesta al Ítem (TRI). Los criterios de exclusión retuvieron items con valores adecuados de comunalidades y cargas factoriales. La estimación de los parámetros TRI, la Curva de Característica del Ítem (CCI) y test de información orientaron la selección de los items de mejor calidad. El ajuste del modelo final se evalúo con la Raíz de la Media de los Cuadrados de los Errores de Aproximación (RMSEA), Raiz Estandarizada de la Media Cuadrática Residual (SRMSR), Índice de Ajuste Comparativo (CFI) e Índice de Tucker-Lewis (TLI). Se describieron las actitudes alimentarias en cada nivel de la DEAS-s. Los análisis se realizaron con el software R y con Microsoft Excel, versión 2013. En los resultados, seis items se excluyeron, debido a comunalidades y cargas factoriales bajas, y un item más se excluyó, debido a una sobreposición en la CCI. Los 17 items restantes explicaron 0,53 de la variancia total y mostraron un ajuste adecuado $(R M S E A=0,05 ;$ SRMSR =0,05; $C F I=0,98$; $T L I=0,98)$. El test de información es más preciso entre los escores $0 y+3$. Valores mayores o iguales de 1,5 identificaron a individuos con comer desordenado. Las mujeres, los mayores y los individuos con indice de masa corporal más elevado presentaron más comer desordenado. Por tanto, la versión unidimensional y breve de la DEAS mostró ajuste adecuado y puede contribuir a la evaluación correcta de los trastornos alimentarios en poblaciones distintas.

Psicometría; Análisis Multivariante; Trastornos de la Ingesta de Alimentos; Cuestionarios; Confiabilidad $y$ Validez
Submitted on 09/Sep/2019

Final version resubmitted on 05/Nov/2019

Approved on 19/Nov/2019 